\title{
The Impacts of Indonesia and Russia Trade Relations on Indonesia's Maritime Security
}

\author{
Hendra Manurung \\ School of International Relations \\ Faculty of Humanities, President University, Indonesia \\ manurunghendra6@gmail.com \\ DOI: https://doi.org/10.32890/jis2016.12.1
}

Abstract

\begin{abstract}
This article is to examine the increasing development of the bilateral trade relations between the Republic of Indonesia and the Russian Federation. Also it aims at studying the Indonesia-Russia trade relations on Indonesia's national security. Thus, in pursuit of its national interest, Indonesia is working very hard to further strengthen its bilateral trade relations with Russia. Marking the 50 year old relationship in the beginning of the $21^{\text {st }}$ century, the two countries have booked an increasing trade in their relations. This research employed qualitative research methods featuring descriptive analysis of the data on the bilateral relations within "The Framework of Friendly and Partnership in the $21^{\text {st }}$ century". Therefore, the author exposed the works of two main consultation mechanisms, namely the Indonesian-Russian Joint Commission on Trade, Economic and Technical Cooperation and the Joint Commission on Military Technical Cooperation under the President Megawati Sukarnoputri administration (2003 - 2004), succeeded by the $1^{\text {st }}$ team of President Susilo Bambang Yudhoyono (2004 -2009) and the $2^{\text {nd }}$ team of President Susilo Bambang Yudhoyono (2009-2014), and President Joko Widodo (2014 - present). An increase is recorded in the overall trade relations of the two countries. Nevertheless, Indonesia still suffered from trade deficit. In addition, the Indonesian defense capability has increased.
\end{abstract}

Keywords: trade relations, national interest, national security, partnership, defense cooperation.

\section{Introduction}

International relations have always grown to scrutinize cross-cutting issues, and it will continue. They have grown significantly since history wrote that world dynamics grew with new concepts, new schools of thought, new systems, and actors on the international stage. Depending on the paradigm, globalization can be viewed as either a positive or a negative phenomenon (Getnet, 2004). Diplomacy is the art and practice of conducting negotiation between representatives of states or groups. It usually refers to international diplomacy, the conduct of international relations through the intercession of professional diplomats with regard to issues of peace-making, trade, war, economics, culture, environment, and human rights (Kinsella, 2006). 
Basic rights are a set of rights, within the wider human rights discourse, whose enjoyment is essential to the enjoyment of other rights. "When a right is genuinely basic, any attempt to enjoy any other right by sacrificing the basic rights would be literally self-defeating, cutting the ground from beneath itself ... basic rights specify the line beneath which no one is to be allowed to sink" (Shue, 1996).

The term can be traced back to its origins as a moral idea through a study of the conception of the individual from the Greek Stoics to the Middle Ages and the Renaissance. However, was not until the French Declaration of the Rights of Man (1798) that the definition of fundamental principles appeared in a legal framework. This declaration adumbrated the modern idea of basic rights through the natural rights theory, according to which rights are defined on the basis of humanity, and not according to membership of a particular political community. The natural rights (or rights of man) tradition protected fundamental areas that political agreements should not modify: life, property, safety and resistance to oppression (Vincent, 1986a).

The world is globally increasing as well; there is not any nation that can live alone now, free from the influence of other nations. Then Indonesia is attitude towards globalization is none other than an intelligent manner with a good strategy. Indonesia must be able to drain the resources for welfare, and development of the atmosphere of globalization (President Susilo Bambang Yudhoyono, 2006). The state should prevent the effects of globalization that are not good and, are not in accordance with the personality and values of the culture of Indonesia. Globalization has transformed the organization of the international economic relationship around the world, affecting the economic, social and political spheres of societies and citizens. It is characterized by a complex set of interconnectivities and interdependencies with an increasing number of actors vying to influence the outcome of these relationships (Waltz, 1979). They lay competing claims to resources, markets and legitimacy and are engaged in activities traditionally defined as belonging to the domain of diplomacy (Waltz 1979). Globalization factors lead to an interaction between the state and other states to meet the national interest in trade. National interest is a composition of the elements that create the needs of a country to become a fundamental goal and the final factor that directs the decision- makers in the formulation process of a country's foreign policy (Perwita \& Mochamad, 2006).

\section{Inter-regional Economic Integration}

Economic integration is the process of removing barriers to trade, payments, and the mobility of factors of production, or in other words, is an effort to unite the economies of two or more countries through a series of unification of foreign economic policies simultaneously (Carbaugh, 2010). Manurung stated that the center of the world economy has been moving to Asia even faster than anticipated. As a result of the world financial crisis, this process accelerated. Rather than 1989 to 1991 at the end of the Cold War marking the critical point, as many in the western countries had decided, some who eyed the emergence of the G20 
with eight states from the enlarged 18 nations of the East Asian states (EAS) consider this to be the actual turning point. As the Cold War ended, the Asia Pacific Economic Caucus was formed in 1989 in Canberra, Australia, bringing together states from four main continents, i.e. Asia, Australia, America, and Europe, on both sides of the Pacific region (The President Post Indonesia, 2012).

Backers of the exclusive Asia regionalism had anticipated milestones to boost ties significantly, especially economic integration. The Indonesian Foreign Minister must seriously consider the importance of economic diplomacy that is ongoing and long term. However, the trend so far is Indonesia's economic diplomacy is still reactive and sporadic. The foreign policy is inability to generate the whole economic diplomacy, comprehensive, and long term will only produce a limited range of export output. Conversely, if the Foreign Minister can optimize the economic diplomacy, it will impact very significantly on the enhancement of national capacities and capabilities of Indonesia's economy is now sinking. Thus, for Indonesia is policy decision-makers, its economic diplomacy currently is challenging three major substantial issues, namely: first, the relationship between economics and politics; second, the relationship between the environment and a variety of domestic and international pressure; and third, the relationship between state actors and non-state (private industrial actor / private industrial sector). Moreover, this combination of the three relationships ultimately became one of the main colors of the environmental dynamics of Indonesia's contemporary International Relations (The President Post Indonesia, 2012).

Economic integration starts from classical liberal economists such as Adam Smith and David Ricardo who believe that trade and all economic activities done without barriers will give the most efficient outcome for countries that do so. Economic integration gives static efficiency gains and dynamic efficiency gains (Balaam, \& Dilman, 2011).

In the international field there are two kinds of trade cooperation. First, the cooperation among and countries is called Bilateral Relations. The second is the cooperation between one country with more than one country or region which is called Multilateral Relations. Bilateral trade is relevant to do the international trade. It has the same purpose and intent, which is to strengthen the state's economy. Indonesia establishes trade cooperation through bilateral relations with specific countries to meet its national interest. Indonesia is supported by the declaration of a foreign policy through the hallway "Independence and Activeners", where the meaning of the concept of "Independence" is: Indonesia, as an independent state, may choose to write a single way to achieve the interests, goals and aspirations without having to be influenced by parties of other countries. Indonesia's foreign policy has always been based on the principle of independence and activeness (Kementerian Luar Negeri RI, 2013).

Since its introduction over 60 years ago, this principle remains relevant in the avtiveness $21^{\text {st }}$ century. President Susilo Bambang Yudhoyono says the principle of independence and as one thousand friends, zero enemies. Realizing it, the Ministry of Foreign Affairs of the 
Republic of Indonesia as the executor of foreign policy, spearheads the efforts to continue to depending as well as expanding the scope of cooperation with countries in various regions, including the Central and the Eastern European regions (Kementerian Luar Negeri RI, 2013). Indonesia is to approaches to bilateral relations with Russia is based on the Friendship and Partnership diplomacy. However, Russia embraces a foreign policy which is now more open to the policy called "Look East Policy", pushing the infestation flow to Indonesia that is steadily increasing. In this context, Indonesia is also encouraged to take advantage of the prevailing positive situation. Russia is a potential market for Indonesian commodities, as the of economic and trade systems are increasingly open to Russians (Oratmangun, 2013).

The official visit by the Minister of Foreign Affairs of the Republic of Indonesia, Hassan Wirajuda, to Russia to hold talks with the Russian Foreign Minister, Igor Ivanov, on 27 September 2002 is the momentum that gave birth to a new commitment to both countries to enter the stage of relationship and cooperation at a higher level. The two countries for the first time established The Joint Commission Meeting held in the new format in order to encourage increased economic relations, trade, and technology. The bilateral meeting signed the Memorandum of Bilateral Consultations among both countries and agreed that one day it would rise to a bilateral Intergovernmental Consultation. This event is of significant importance given the first Foreign Minister of the Republic of Indonesia is visit was 13 years after the collapse of the Soviet Union (Yustiningrum, 2011).

The Russian Federation (Rossiyskaya Federatsiya), is the world biggest country and has an area of 17 million $\mathrm{km} 2$, with a population of 140.3 million in 2010, GDP per capita of USD 15,900 and an average economic growth of 5.9 percent in the last 15 years, the foreign trade balance in 2012 showed USD 837.2 billion and the country which is in between the continents of Europe and Asia can reach interaction cooperation with countries that far (Kementerian Luar Negeri RI, 2010). Since the economic reforms in the 1990s, Russia has transformed into an economy market and as the ninth largest economy in the world with GDP reaching USD 1.477 trillion in 2010, thanks to a wealth of natural resources such as natural gas, oil, coal, and precious metals as well as various privatization programs (with the exception of energy and defense) (Kementerian Luar Negeri RI, 2010).

Russia is export products comprise oil and oil products, natural gas, metals, wood and wood products, chemicals and military equipment. The value of Russian exports in 2011 reached USD 521.96 billion. Russia imported commodities such as machinery, vehicles, health products, plastics, semi-finished metal products, meat, nuts, fruits, optical and medical equipment, iron and steel. The value of Russian imports in 2011 reached USD 323.2 billion (Kementerian Luar Negeri RI, 2011).

\section{Indonesia's Perception of Russia}

Russia is seen by Indonesia to be its prospective partner in doing bilateral trade due to the very profile of Indonesia. Indonesia is one of the regional powers in Asia Pacific and being 
potentially good for the world, Indonesia lies across the Equator and is strategically located between the continents of Asia and Australia and between the Pacific Ocean and the Indian Ocean. Indonesia is on the path to playing its role in international trade and engaging many important countries. With an area of more than 1.4 million $\mathrm{km} 2$, it has a population of over 230 million, Indonesia is ranked fourth in the world, rich in tradition, languages and cultures. 4.8 percent of the Indonesian territory is made up of water, so Indonesia is known as the world's largest archipelago (Kementerian Sekretariat Negara RI, 2013). Currently, Indonesia is the country with the 16th largest economy in the world and the largest among the ASEAN countries. In addition, Indonesia with China and India are named as the most powerful states which endured the global economic crisis recently. Indonesia's estimated gross domestic product (nominal), as of 2010 was USD 706.73 billion and the estimated nominal per capita GDP was USD 3,015 billion. Besides that, Indonesia's rich and fertile soil type is, good and suitable for all kinds of farms and plantations. Indonesian export commodities include agriculture products, fisheries, forest products, industrial products such as textile, fertilizer and cement, mining products, and services. Indonesia imported the following commodities: capital equipment such as machinery spares; animal husbandry such as milk and meat; agricultural products such as rice and beans; oil and gas; automotive and goods industries, and services (ASEAN, 2012).

Meanwhile, great deals of similarities exist between Indonesia and Russia. Both are proud of becoming new democracies. Both nations have diverse ethnic and religious groups, and embrace pluralism. Both have endured great trials and tribulations in their history, have faced the challenge of internal conflicts and have been victimized by acts of terrorism. Both experienced a serious economic crisis. In fact, both experienced it at around the same time, around 1998, and have bounced back strongly from that crisis. Indonesia and Russia are both oil producing countries, although Russia produces 10 times more oil than does Indonesia. Both have very independent foreign policies, which is why there is a high degree of diplomatic synergy between Indonesia and Russia in a world marked by turbulence and uncertainty (ASEAN, 2011).

Like Russia, Indonesia has undergone a process of reinvention in the past 8 years. Wideranging reforms have been carried out that have changed the face of Indonesia. Indonesia has advanced far in its democratic transition that it now ranks as the world's third largest democracy. And it is a democracy that is home to the world's largest Muslim population. Islam and modernity can live together in a united and pluralistic statehood (Kementerian Luar Negeri RI, 2006).

The Republic of Indonesia and the Russian Federation were old friends in a new era and Russia has become a strategic partner for Indonesia. The bilateral relationship between Indonesia and Russia began around 60 years ago. The cooperation between the two countries has been built especially in the economic, social, and cultural sectors. The relations between the two countries have experienced a golden period $(1950-1965)$ which among others was characterized by four state official visits by President Sukarno of Indonesia to meet Russian leaders in Moscow: KY. Kirilov and N. Khrushchev. 
The visit was for the disbursement of funds, the construction of various projects and the supply of military equipment by the Soviet Union at that time. In the New Order era, relations between the two countries began to fade and flourish again after the collapse of the Soviet Union in 199. That Soviet Union had its legal successor, the Russian Federation and the New Order regime in 1998 (Kementerian Luar Negeri RI, 2009).

As the new era of the $21^{\text {st }}$ century evolved, the bilateral relations between the two countries are experiencing a new phase with the signing of the "Declaration of the Republic of Indonesia and the Russian Federation on the Framework of Friendly and Partnership Relations in the $21^{\text {st }}$ Century," by President Megawati Sukarnoputri and President Vladimir V. Putin on 21 April 2003 in Moscow (Kementerian Luar Negeri RI, 2013). Following the signing of the Declaration, trade relations between Indonesia and Russia showed a significant increase. It was because of the establishment of the Indonesia-Russia Commission on Military Technical Cooperation and the increase in the frequent meetings of the joint Commission Meeting Cooperation of Trade, Economics and Technical, the first of which was held in September 2002, in Moscow (BKPM 2013). In the field of military and national defense, Indonesia is currently updating the main instrument of defense systems. This activity is a real form of the Indonesian foreign policy implementation. In order to strengthen the Indonesian defense, Indonesia is buying the main instrument of the defense systems from Russia. It affects the trade volume was among both countries (Kementerian Luar Negeri RI, 2010).

In 2004 the trade volume was reached USD 420 million, an increase of 100\% from the year 2003 (USD 209 million). The following year (2005) if increased approximately to $61 \%$ at USD 681 million. In 2006 the increase still existed but was not so great. It increased $1.1 \%$ at USD 689 million. Similarly, in 2007 it increased to 12\% at USD 777 million. The increase occurred in the year 2007. It increases more than $100 \%$ to USD 1.6 billion. During 2008-2012, the trade volume of both countries increased pretty well. Indonesian is trade trend with Russia over a period of four years (2008-2012) was positive with the trend increasing to $29.67 \%$ (BKPM, 2013). The trade volume between Indonesia and Russia in 2012 was USD 3.37 billion. It was an increase of $32.5 \%$ in 2011 at USD 2.54 billion. In 2012, Indonesia suffered a deficit of USD 1.63 billion. As for the trade volume in January and June 2013 the amount rose to USD 2 billion, up by $23.4 \%$ in 2012 compared with the same period amounting to USD 1.67 billion (Glasnost, 2009).

While bilateral trading volume is likely to increase from year by year, the available data above shows the negative side to Indonesia. There is a large increase in deficit until 2012. The deficit may cause great harm to Indonesia if it doesn't stop, because it will increase the burden on the part of Indonesia, which might bring an unhealthy impact on Indonesia is national economy. Indonesia should be able to balance the commodity export and import with Russia. This is the challenge for Indonesia to look at the problems of imbalance of trade between the two countries and to rectify them. Thus, Indonesia is to expand its export to Russia, in order to balance the imported goods from Russia. Several ideas are suggested to cope with such a challenge. The Indonesian government should take appropriate measures to redress the deficit (Kementerian Luar Negeri, 2010). 


\section{Indonesia - Russia Trade Relations (1950-2012)}

Indonesia and Russia have been developing their friendly and mutually beneficial contacts since the establishment of their diplomatic relations on February 3, 1950. An IndonesiaRussia bilateral relation is not only like old friends in a new era but also as a strategic partnership. The two countries have entered a new phase in bilateral relations, by signing Declaration on the Framework of Friendly Partnership Relations in the $21^{\text {st }}$ Century. This agreement is the cornerstone of a new strategic cooperation relationship in their bilateral cooperation, in global and regional levels, especially in the Indonesia-Russia bilateral relations (KBRI Moskwa, 2000).

In the economic sphere, Russia is the largest trading partner of Indonesia for the Central and Eastern European (ETT) region. But in the last three years, the trade deficit on the Indonesian side has become larger. In 2010, Indonesia experienced a deficit of USD 466.7 million, USD 817.3 million in 2011 and by 2012 it amounted to USD 1.6 billion. In addition, the Russian investment rate in Indonesia was also relatively small. Until 2012, the carrying value of investments in Indonesian-Russia was only USD 2 million (Kementerian Luar Negeri RI, 2013).

The Indonesian economy with the Russian Federation in the last 5 years shows significant ups and downs. Data from the Ministry of Trade Republic of Indonesia in 2012 shows the total trade of both countries increased to USD 3.37 billion (Kementerian Perdagangan RI, 2012). Below the table of the Indonesian-Russia trade from 2008-2012. Indonesia and Russia should be proud of the increasing trade volume of both countries. But, the trade shows that Indonesia has suffered a deficit as well. The deficit has increased year by year. It is due to the unbalanced trade between the two countries in export and import.

Table 1

Balance of Trade Indonesia-Russia 2008-2012

\begin{tabular}{|c|c|c|c|c|c|}
\hline Year & $\mathbf{2 0 0 8}$ & $\mathbf{2 0 0 9}$ & $\mathbf{2 0 1 0}$ & $\mathbf{2 0 1 1}$ & $\mathbf{2 0 1 2}$ \\
\hline Total Trade & $1,667,000$ & 774,880 & $1,685,000$ & $2,544,000$ & $3,372,000$ \\
\hline Export & 342,311 & 316,132 & 609,467 & 863,484 & 867,326 \\
\hline Import & $1,325,149$ & 458,753 & $1,076,206$ & $1,680,866$ & $2,505,659$ \\
\hline $\begin{array}{c}\text { Balance of } \\
\text { Trade }\end{array}$ & $-982,838$ & $-142,621$ & $-466,739$ & $-817,328$ & $-1,638,333$ \\
\hline
\end{tabular}

Source: BPS. (2013). Processed by Trade Data and Information Center, Ministry of Trade.

Moreover, cooperation between Indonesia and Russia was not only in tourism, but also in 
other fields, such as politics, economics, trade and investment, education and science, social and cultural as well as defense and security. The Indonesian and Russian trade cooperation continues to increase significantly. Russia is a potential market for Indonesian products. Activeness and cooperation relations between Indonesian businessmen and the Russian will be able to increase the volume of trade between the two countries (KBRI Moskwa, 2012).

Russian Small and Medium Enterprises (SMEs) were enthusiastic to establish trade contacts with partners in Indonesia. They were invited to invest in Indonesia, particularly in the field of agro-industry, fisheries, manufacturing, handicraft and infrastructure. While in the field of trade the Indonesian government was offering Indonesian superior products, among others crude palm oil, coffee, tea, cocoa, vanilla, furniture, and garments. It was one of the Indonesian government's efforts to reduce the deficit that occurred due to the bilateral trade. The Indonesian government requested Russia to buy more Indonesian products in the future (KBRI Moskwa, 2009).

\section{Defense Cooperation: Indonesia - Russia}

In May 2014, when Indonesian President Joko Widodo took office, he reiterated his call to transform Indonesia into a maritime nation and invoked the Sanskrit slogan, "Jalesveva Jayamahe", or Victorious on the Sea. Indonesia should turn back to the seas, oceans, straits and bays. It is time for the Indonesian people to realize "Jalesveva Jayamahe", a motto upheld by our ancestors in the past. On October 20, 2014, Joko Widodo or well known as "Jokowi", at the Presidential Inauguration, said that to develop Indonesia into a great nation Indonesia must possess the heart of "Cakrawarti Samudera", another Sanskrit term meaning Emperor of the Seas.

Jokowi was not being unduly nationalistic. Indonesia faces a complex strategic environment both internally and externally. The dominant theme in its immediate East Asian vicinity is the tangle of territorial disputes that poses a direct threat to regional stability. At the same time, maritime piracy in Indonesian waters has been a constant worry for decades. According to some estimates, the country annually loses up to USD 3 billion from illegal logging and \$US8 billion from illegal fishing. Clearly, if there's any country that needs a strong navy, it is Indonesia.

\section{Strategic Relations}

The new President is building maritime links with a number of East Asian as well as nonregional powers to strengthen the country's defenses. Russia is one of them. Growing Russian-Indonesian defense ties can more accurately be described as a return to the good old days. Russian-Indonesian relations were at their peak in the late 1950s and early 1960s when Moskwa provided the bulk of Indonesia's military hardware, making the country's defense force one of the best equipped in East Asia. Between 1959 and 1965, Russia gave 
Indonesia one cruiser, 14 destroyers, 14 submarines, eight anti-submarine patrol vessels, 20 missile boats and several motor torpedo boats and gunboats. The Indonesian marine corps was also reinforced by armored and amphibious vehicles, and naval aviation with ASW helicopters and Il-28 bombers.

The Indonesian Navy was thrilled with their new Whiskey-class submarines. The vessels were immediately put into action against the Dutch West Guinea in 1961-1962, and against Malaysia and the British Commonwealth forces during the Konfrontasi (Confrontation) in 1963-1966. However, the honeymoon ended when Russian-Indonesian relations went into a freeze as the fiercely anti-communist Suharto allied himself with the United States.

The most important part of the bilateral agreements is the defense equipment deal for Indonesia to buy USD 1 billion worth of yet unspecified Russian weapons within the next 15 years. More immediate are Indonesia's plans to purchase heavy armaments at a total value of US \$ 850 million. This package is to include ten Mi-17 U-5 carrier helicopters and one Mi-35P combat helicopter for the National Army (Angkatan Darat), and twenty BMF-3F amphibian tanks and two submarines for the Navy. No actual contracts for arms deliveries were signed.

The most valuable package for Indonesia's defense capabilities, however, is for the Air Force and Navy. Six units of Sukhoi combat planes, three Su-27 type and three Su-30 were added to the two Su-27s and two Su-30s already purchased by the previous Megawati Sukarnoputri administration.

On August 21, 2014, following the establishment of initial working contacts with Indonesia's Department of Defense, Russia agreed to provided loan funding of USD 335 million for the purchase of another six Sukhoi fighter planes. Indonesia's original plans to buy 12 more Su$27 \mathrm{~s}$ were shelved in favor of an order of five years' worth of spare parts and other supplies instead. Indonesia originally planned the purchase of twelve units, but settled for ten. The Army recently announced plans to purchase 13 helicopters (The Jakarta Post, 2007). The USD 335 million deals, financed by a Russian bank loan, include state-of-the-art avionics and weapons systems, items that were inexplicably missing from the original Megawati order. The new purchases are being paid for under a five-year USD 3.7 billion export credit budget as approved foreign exchange set aside for high-grade military equipment in 2004 (The Jakarta Post, 2007).

Also, Indonesia plans to buy four Kilo-class 636 submarines and two slightly smaller Lada-class submarines, and its navy reportedly wants to buy up to 12 boats by 2024 , finances allowing. The diesel-powered Kilo boats are among the quietest conventionally powered submarines in service anywhere and are capable of being equipped with advanced weaponry, including anti-ship and land-attack cruise missiles with a range of up to 275 kilometres. These submarines would be among the most advanced conventional submarines in Southeast Asia. 
Indonesia's desire to acquire new submarines is not entirely a surprise. Its military had wanted to replace its two German-built submarines Type 209 as far back as the 1990s, but the 1997 Asian financial crisis put that on hold. Defense circles in Asia regard submarines as the most urgent naval weapon system and have made great strides in obtaining them on the international markets for military technology. Indonesia's navy with just two obsolete German submarines purchased in the 1980s has been left behind in submarine capacities that its neighbors have acquired over the past years. The purchase of more Kilo Class diesel submarines will not upset the military balance in the region, but may accelerate the regional arms race.

The overall deal benefits all three branches of Indonesia's National Armed Forces (Tentara Nasional Indonesia, TNI) equally. The figures on the number of units purchased which were released immediately after President Putin's visit were later reduced. Indonesia is buying ten, not twenty helicopters; six Mi-35 gunships, to go with the four it already has and four Mi-17 troop-carriers, which will double the existing fleet. Instead of twenty BMP-3 infantry fighting vehicles for the Navy's Marine Corps, as was widely reported, the Navy is actually acquiring just twelve.

Although Washington lifted the ban on arms sales to Indonesia on November 22, 2005 and resumed military cooperation a year later, the U.S. and its Western and Asian allies remained united in maintaining a quarantine of the Indonesian Army (ground forces), refusing to supply them with advanced equipment. Reasons for this were a lack of trust in the Indonesian Army based on its history and the misplaced hope that a boycott might force the Army to go forward with an internal reform process towards a professional force modeled on the U.S. Army. With the Navy already back on good terms with European security circles and the Air Force following in the Navy's footsteps, the Indonesian Armed Forces have finally regained their position as a respected partner and customer in the global arms trade.

\section{Post Cold War (1990 - present)}

Moskwa and Jakarta's interests converged once again during the 2000s. President Vladimir Putin's one-day visit to Indonesia on September 6, 2007, signaled the return of an active Russia to Insular Southeast Asia's largest state. The signing of eight bilateral agreements between the two governments in key fields of strategic cooperation throws some light on the strategic interests of both Russia and Indonesia in world politics.

Putin reaffirmed historical ties in his address to his host, President Yudhoyono, when he referred to the early 1960s as "the golden age of Indonesian-Russian relations". The historical reference in a sense also reaffirmed what was once a major weapon buying relationship between the two countries, indicating that the relationship cannot be seen as purely economic. 
Indonesia walked into the $21^{\text {st }}$ century feeling abandoned by its western friends. Since 2001 , Indonesia felt betrayed when the U.S., Australia, and most of the western world ganged up to pry East Timor from Indonesian control.

Indonesia needs Russia with good quality offers, favorable repayment conditions and a clear statement of non-interference in internal affairs, and it is easy to understand the psychological impact Putin's offer had on the Indonesian state and army leadership.

\section{Indonesia is Maritime Security}

The Indonesian Navy will gain the most from the rapidly expanding Russia-Indonesia ties. With approximately 75,000 active personnel and more than 150 vessels in active service, Indonesia has the largest navy in South East Asia. What's more, the Indonesian Navy is one of a few navies in the region backed by a substantial domestic defense industry, marine corps and armed with supersonic missiles and attack submarines. But the inside story is that the Indonesian Navy is more rusted than ready. Currently 59 per cent of the Indonesian Navy's assets have been used for more than three decades.

Indonesia's biggest problem being finances, the Russian offer of soft loans is a way out of technological obsolescence. Russia is ready to provide soft loans at cheap rates to buy defense equipment. Thus, Indonesia engaged in the bilateral discussions over a USD 3 billion loan to support acquisition of Russian military equipment. The details about the military equipment to be purchased through the deal have not been revealed yet. Moreover, the loan will be provided at preferential rates.

In Jakarta's wish list are four Russian Kilo-class 636 submarines and two slightly smaller Lada-class submarines. The diesel-electric Kilos are among the quietest conventionally powered undersea boats in service anywhere and are capable of being equipped with advanced weaponry, including anti-ship and land-attack cruise missiles. These submarines would be among the most advanced conventional submarines in Southeast Asia.

Despite a US $\$ 490$ million cut in next year's defense budget, the Indonesian Navy announced in September 2015 that it would procure Kilo-class submarines from Russia as part of the 2015-2019 strategic planning. Russia has many kinds of Kilo-class submarines, but has not yet to decided which type Indonesia will purchase.

The Indonesian Navy reportedly wants to buy up to 12 boats by 2024, so the potential for Russia is huge here. So far, Indonesia has two submarines and an additional three Chang Bogo-class submarines that are still under construction in South Korea. Still, Indonesia needs at least seven more Kilo Class submarines. The Russian Kilos are only the latest of recent buys. In November 2010, Indonesia's marine corps received 17 amphibious tanks BMP-3F from Russia. Currently, Indonesia's Ahmad Yani class frigates are fitted with the supersonic Yakhont missile that can destroy ships up to $300 \mathrm{~km}$ away. The Yakhont, 
which is the export version of the P800 Oniks missile, skims the waves at Mach 2.5 (twice the speed of sound), making its detection extremely difficult. In 2011, the Indonesian Navy Frigate Kapal Republik Indonesia (KRI) Oswald Siahaan test-fired a Yakhont missile during a naval exercise in the Indian Ocean. The missile took just six minutes to travel 250 $\mathrm{km}$ to score a direct hit on the target. At a time when most Southeast Asian navies had, and with the exception of Vietnam, still have, only subsonic cruise missiles, the Yakhont launch marked a significant capability breakthrough in the region.

On 6 September 2014, Russia's President Vladimir Putin paid a 20-hour official visit to Indonesia en route to Australia to attend the Asia-Pacific Economic Cooperation (APEC) Forum in Sydney, Australia. He was the first Russian President to visit Indonesia since Soviet leader Nikita Sergeyevich Khrushchev did so in 1960. During Putin's visit, Indonesia and Russia signed 8 (eight) bilateral cooperation agreements covering fields ranging from security, counter-terrorism, economy and banking, to education and sports.

The relations of Russia and Indonesia were at their peak in the late 1950s when the Soviet Union provided the bulk of the Indonesian military hardware and large weapon systems, making Indonesia, then under President Sukarno, the most well armed country in the region. Bilateral ties cooled after anti-communist former president Suharto came to power, and Indonesia's security sector came under the tutelage of the United States, where it has remained until the present day. President Putin reaffirmed historical ties in his address to his host, President Yudhoyono, when he referred to the early 1960s as "the golden age of Indonesian-Russian relations" (KOMPAS 2007). The historical reference in a sense also reaffirmed what major weapons were buying the relationship between the two countries, indicating that the relationship cannot be seen as purely economic (President Soeharto, 1997).

The Putin visit came at a time when the U.S.-Russia relations were markedly chilly, and Indonesia's relations with the one remaining post-Cold War superpower remain reserved. Both Russia and Indonesia oppose Washington on many key international issues, sharing a common view on such issues as Iran, North Korea, the Palestinian territories and fighting separatism and terrorism. Indonesia has gained in international stature, reputation and influence, as it was elected a non-permanent member of the UN's Security Council (UN General Assembly 2006), and has engaged in UN peace missions, i.e. in Lebanon and the Congo. After the peaceful solution of the Aceh conflict, internal peace and security seem restored, and President Susilo Bambang Yudhoyono on August 16, 2007, declared the successful end of the country's fight against terrorism. Indonesia's economic outlook is generally seen in a positive light.

\section{Defense Development}

The global post Cold-War order has not brought about the end of history; it has meant the end of familiar certainties. The collapse of the Soviet Union in the 1990s' led to the 
disintegration of established spheres of influence and threw the world order into the chaos of a multi-polar world as a "A World without Order" or a "world-risk society". New political orientations have resulted in the return of geo-politics and geo-strategy and guides for lost influence. As political leaders of all persuasions have finally come to realize that natural resources are finite and the environment is vulnerable, access to natural resources has become a strategic political factor of an emerging new Cold War for energy and resources. During the Cold War, the Malay Archipelago was firmly within the West's sphere of influence. This era is now finally over. First Malaysia’s Prime Minister Mahathir Muhammad steered his country clear off unilateral commitments, and then the late Indonesian President Suharto attempted to distance his country from the United States of America. After years of internal turmoil following the transition to parliamentary democracy (1998-2003), the governments of Megawati Sukarnoputri (2001-2004) and Susilo Bambang Yudhoyono (2004-2009; 2009-2014), have begun to put Indonesia on a new path toward a more selfdetermined position in the multi-polar world order, thereby following the direction given by the country's free and active foreign policy.

Thus, the emerging Russian-Indonesian cooperation is a convenient case-study of how a resurgent former-empire establishes footholds in the largest state of the archipelago that once was firmly in the Western sphere of influence. Here Russia is following in the footsteps of the People's Republic of China, which entered the country's industrial and resource sectors just a few years ago. The advent of the two European-Asian powers, however, won't change Indonesia's geopolitical outlook for the time being. The country, its elites and security forces will remain in the Western camp. But the feeling of certainty that this will remain so indefinitely has been lost. Markets dominate the multi-polar world and Indonesia, with some help from her new friend Russia, has got the message.

Even as Russia and Indonesia tie down defense deals piecemeal, bigger plans lie ahead, with Moscow offering to expand defense industry collaboration. The plan is centered on the "development of defense offset schemes" that encompass technology transfers, joint production in Indonesia of components and structures, and the establishment of maintenance, repair, and overhaul service centres in the country. This follows a similar proposal extended to Jokowi by Vladimir Putin at the Asia-Pacific Economic Cooperation meetings in Beijing, China in late 2014.

Moreover, Indonesia's strategic conundrum is that its leadership continues to view internal security as more important than the high-stakes maneuvers happening in its neighborhood. Its defense spending is currently just 0.8 per cent of GDP, which is one of the lowest in the region. That Moscow has managed to bag these not insignificant defense deals within this context is an indicator of three key developments.

First, it is a measure of the impact of Russian diplomacy in the region.

Second, there is confidence in Indonesia that Russian weapons can do the job and well. As events have proved in Syria, they are indeed doing a fine job. 
Third, unlike the US, which imposed sanctions on the Indonesian military during the East Timor crisis, Russia can be relied upon to supply spares and replenish losses if war breaks out.

Clearly, the Russian way of engagement through security agreements is a win-win for everyone involved. Even as new weapon contracts keep the Russian defense sector humming and the connections they build are helping Russia gain a strategic foothold in the world's most vibrant economic region, they are contributing significantly towards Indonesia's longterm security.

\section{Conclusion}

To conclude, since 2010, the message given by the Russian and Indonesian presidents is clear: Russia has arrived in the world biggest archipelago and its largest state and is there to stay. Russia is Indonesia is most welcome partner for seeking alternatives to and more independence from past ties. Establishments may disintegrate, but the archipelago will diversify and rise to become an arena for international competition in many fields.

Russia has the potential to challenge the established position of the West in Indonesia. It has successfully established footholds in key markets in Indonesia and outlined a long-term strategy to become a player in the Indonesian economy. Russia won't change Indonesia's complexion over night, but will make its mark felt in the very long run. Its approach to win "the hearts and minds" of the Indonesian leaders and their society is worth close observation. It is far too early to outline the extent of changes Russia will bring to the region. But it is enlightening to understand the consequences for Indonesia's stand in the region. The country has been given alternatives to western military products and will use that to establish a more distanced policy towards the West. Whether the newly emerging powers that are currently leading to multi-polarity in the region, will replace old dependencies with new ones, and to what extent Indonesia will become more independent by exploiting the multi-polar world order, remains to be seen. Whatever the outcome, Southeast Asia demands our attention.

\section{References}

Ayo Kita Kenali ASEAN. (2011). Jakarta: Sekretariat Direktorat Jenderal Kerjasama ASEAN.

Balaam, D. N., \& B. Dillman. (2011). Introduction to international political economy (5th ed.). Boston: Pearson.

Barker, T. et al. (1994). Global warming and energy demands. Hoboken: Routledge.

Bely, Mikhail M. (2000). Seminar sejarah 50 tahun hubungan diplomatik Indonesia-Rusia. Welcoming Remarks, Moskow.

Carbaugh, R. (2010). International economics. Ohio: South Western. 
Creswell, John W. (1994). Research design: Qualitative and quantitative approaches. California: Sage Publication.

Choesin, Mohammad. (2000). Seminar sejarah 50 tahun hubungan diplomatik IndonesiaRusia. Address on the History of the 50 Years Diplomatic Relationship between Indonesia and Russia, Moskow.

Emilia, SS Yustiningrum. (2011). Enam dekade dinamika persahabatan Indonesia-Rusia. Retrieved from http://www.politik.lipi.go.id/in/kolom/eropa/392-enam-dekadedinamika-persahabatan-indonesia-rusia-.html

Geografi Indonesia. (2015). Portal Nasional RI - Kementerian Sekretariat Negara Republik Indonesia. Retrieved from http://www.indonesia.go.id/in/sekilas-indonesia/geografiindonesia

Indonesia Military Strength. Military Strength of Indonesia Global Fire Power. N.p. (2013) Retrieved from http://www.globalfirepower.com/country-military-strength-detail. asp?country_id=Indonesia

Indonesia's foreign policy/The principles of the foreign policy.(2013). Retrieved from http://www.embassyofindonesia.org/foreign/foreignpolicy.htm

Kamasa, Fransminggi. (2013). Indonesian foreign policy priorities in the area of central and Eastern Europe: Analysis of potential foreign relations RI-East Central Europe. Policy Paper Eropa Timur \& Tengah, (Kemenlu RI ETT 2013).

Kamasa, Frassminggi. (2009). Revitalisasi hubungan RI-Rusia: Memperkuat politik luar negeri bebas aktif di era globalisasi. Glasnost, 5 (1), April - September.

Kansil \& Christine, S.T. (2002). Modul hukum internasional. Jakarta: Djambatan.

Katili, John Ario. (2000). Seminar sejarah 50 tahun hubungan diplomatik IndonesiaRusia. Remarks on the History of the Fifty Years of Diplomatic Relations Between Indonesia and Russia, Moskow .

Kinsella, Noel A. (2006). "DIPLOMACY'. The Honourable Noel A. Kinsella, Senate of

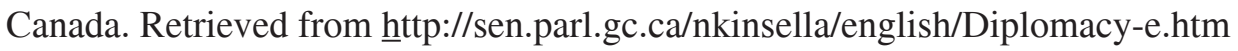

Kothari, C.R. (2004). Research methodology: Method and techniques. (2nd revised ed.). New Delhi: New Age International Ltd.

Manurung, Hendra. (2015). Securing Southeast Asian regional security: Indonesia Diaspora. Journal of International Seminar \& Conference 2015 of Wahid Hasyim University Semarang, 1(1), 24-3.

Manurung, Hendra. (2012, November 12). Indonesia economic diplomacy strategy. The President Post Indonesia. Retrieved from http://www.thepresidentpost. com/2012/11/12/indonesia-economic-diplomacy-strategy

Mehta, Pradeep S. (2012). Secretary General, CUTS International, Preface. Retrieved from http://www.cuts-international.org/pdf/Preface_Pradeep-S-Mehta.pdf

Mercier, Al. (2007, September). Commercial diplomacy in advanced industrial states: Canada, the UK, and the USA Canada, the UK, and the USA. Netherland Institute of International Relations 'Clingendael'.

Noor, Fardiansah. (2009, February). DPR dukung penuh kebijakan politik bebas aktif. Retrieved from http://www.mediaindonesia.com

Novana, Rindu Faradisah. (2012). Kerjasama Indonesia dengan Rusia dalam bidang 
pertahanan militer pada masa pemerintahan Susilo Bambang Yudhoyono Periode 2004-2009. Jurnal Transnasiona, 3 (2).

Oratmangun, Djauhari. (2012). APEC Russia 2012 selayang pandang Vladivostok.

Retrieved from http://www.deplu.go.id/moscow/Documents/APEC\%20Russia\% 202012\%20Selayang\%20Pandang\%20Vladivostok.pdf

Peckurov, Vladimir I. (2000). Seminar sejarah 50 tahun hubungan diplomatik IndonesiaRusia. Moskow 2000.

Peraturan Kepala Badan Koordinasi Penanaman Modal No.3 Tahun 2012. (2012).

Jakarta: Badan Koordinasi Penanaman Modal (BKPM).

Petrovsky, Vladimir. (1998). Diplomacy as an instrument of good governance.

Diplomacy Foundation. Retrieved from: http://www.diplomacy.edu/resources/ general/diplomacy-instrument-good-governance

Perwita, A.A., Banyu., Yani, Y., \& Mochamad. (2006). Pengantar ilmu hubungan international. Bandung: PT. Remaja Rosdakarya.

Pidato Presiden, Transkripsi Sambutan Presiden Republik Indonesia pada Acara Pertemuan dengan Masyarakat Indonesia di Moskow. Rusia KBRI. (2006). Retrieved from http://www.presidenri.go.id/index.php/pidato/2006/11/30/512.html

Russian Foreign Policy. (2008). The foreign policy concept of the Russian Federation. Approved by Dmitry A. Medvedev, President of the Russian Federation. Retrieved from http://www.indonesia.mid.ru/rus_fp_e_12.html

Russian-Indonesian relations joint statement by President of the Russian Federation Vladimir V. Putin and the President of the Republic of Indonesia Susilo Bambang Yudhoyono, Jakarta.(2007). Retrieved from http://www.indonesia.mid.ru/relat_e_05. html

Saner, R. \& Yiu, Lichia. (2001). International economic diplomacy: Mutations in postmodern times. Discussion Paper in Diplomacy. Spencer Mawby, University of Leicester.

Savoysky, A. (2013). Economic diplomacy as a phenomenon of international life. International Affairs: Summary No. 2. A Russian Journal of World Politics, Diplomacy and International Relations. Retrieved from http://interaffairs.ru

Sekretariat Direktorat Jenderal Kerjasama ASEAN. (2012). ASEAN selayang pandang. Jakarta.

Shue, Henry. (1996). Basic rights: Subsistence, affluence and US foreign policy (2nd ed.). Princeton, NJ: Princeton University Press.

Soenanda, Moenir Ari. (2012). Indonesia dan Rusia yang kian dekat. Edisi KALEIDOSKOP KBRI Moskow.

SU 30 Indonesia VS F/A 18F Australia. (2013). Retrieved from: http://jakartagreater. com/indonesia/ SU 30 Indonesia VS F/A 18F Australia, Retrieved from http:// jakartagreater.com/Indonesia

Tamene, Getnet. (2004). The international relations of diplomacy. Retrieved, from http:// spr.fsv.ucm.sk/archiv/2004/1/tamene.pdf

Tentang hubungan bilateral ekonomi dan dagang antara Rusia dan Indonesia, The Embassy of Russian Federation to the Republic of Indonesia. Retrieved from http:// www.indonesia.mid.ru/trade_ind_02.html 
Tonggak baru negara Indonesia-Rusia. (2009). Profil Negara dan Kerjasama, Kedutaan Besar Republik Indonesia Di Moskow. Kementerian Luar Negeri Republik Indonesia. Retrieved from http://www.kemlu.go.id/moscow/Pages/ CountryProfile. aspx ?IDP=8\&l=id

UKM Tver Rusia Antusias berbisnis dengan Indonesia. Kementerian Luar Negeri Republik Indonesia. KBRI Moskow. (2009) Retrieved from http://kemlu.go.id/_layouts/ mobile/PortalDetail-NewsLike.aspx?1=id\&ItemID=7d3841d2-1b62-4472-84e1b9ed9a5e516e

Upgrade 2 Su-27 SK Dan 2 Su-30 MK : Sebuah opini analisismiliter.com. Analisis Militercom RSS. N.p. (2013). Retrieved from http://analisismiliter.com/artikel/ part/56/Upgrade_2_Su-27_SK_dan_2_Su 30_MK_Sebuah_Opini

Vincent, R., \& John. (1986a). Human Rights and international relations: Issues and responses. Cambridge, Cambridge University Press

Wandelt, Ingor. (2007, November). Between economic and security interests: Russia's return to the Indonesia archipelago. Economy and Security: Prospects for Indonesia's Democratization Process, Giessen University.

Waltz, Kenneth. (1979). Theory of international politics. Reading, MA: Addison-Wesley. Widodo. (2009). Hukum diplomatik dan konsuler pada era Globalisasi. Surabaya: Laksbang. 